\title{
Producer estimates of prevalence and perceived importance of lameness in dairy herds with tiestalls, freestalls, and automated milking systems
}

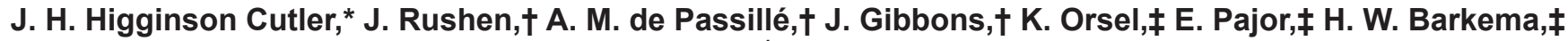 \\ L. Solano,‡ D. Pellerin, $§$ D. Haley, ${ }^{*}$ and E. Vasseur\# ${ }^{1}$ \\ *Department of Population Medicine, Ontario Veterinary College, University of Guelph, Guelph, Ontario, Canada, N1G 2W1 \\ †Dairy Education and Research Centre, University of British Columbia, Agassiz, British Columbia, Canada, V0M 1A0 \\ ‡Department of Production Animal Health, University of Calgary, Calgary, Alberta, Canada, T2N 4N1 \\ §Département des Sciences Animals, Université Laval, Québec City, Québec, Canada, G1V 0A6 \\ \#Department of Animal Science, McGill University, Ste-Anne-de-Bellevue, Québec, Canada, H9X 3V9
}

\begin{abstract}
Lameness is one of the most important welfare and productivity concerns in the dairy industry. Our objectives were to obtain producers' estimates of its prevalence and their perceptions of lameness, and to investigate how producers monitor lameness in tiestall (TS), freestall with milking parlor (FS), and automated milking system (AMS) herds. Forty focal cows per farm in 237 Canadian dairy herds were scored for lameness by trained researchers. On the same day, the producers completed a questionnaire. Mean herd-level prevalence of lameness estimated by producers was $9.0 \%( \pm 0.9 \%$; $\pm \mathrm{SE}$ ), whereas the researchers observed a mean prevalence of $22.2 \%$ ( $\pm 0.9 \%)$. Correlation between producerand researcher-estimated lameness prevalence was low $(\mathrm{r}=0.19)$ and mean researcher prevalence was 1.6, 1.8, and 4.1 times higher in AMS, FS, and TS farms, respectively. A total of $48 \%$ of producers thought lameness was a moderate or major problem in their herds (TS = $34 \%$; AMS $=53 \%$; FS $=59 \%$ ). One third of producers considered lameness the highest ranked health problem they were trying to control, whereas two-thirds of producers $(\mathrm{TS}=43 \%$; AMS $=63 \% ; \mathrm{FS}=71 \%)$ stated that they had made management changes to deal with lameness in the past 2 yr. Almost all producers (98\%) stated they routinely check cows to identify new cases of lameness; however, $40 \%$ of producers did not keep records of lameness $(\mathrm{AMS}=24 \%$; $\mathrm{FS}=23 \%$; $\mathrm{TS}=$ $60 \%)$. A majority (69\%) of producers treated lame cows themselves immediately after detection, whereas $13 \%$ relied on hoof-trimmer or veterinarians to plan treatment. Producers are aware of lameness as an issue in dairy herds and almost all monitor lameness as part of their daily routine. However, producers underestimate
\end{abstract}

Received April 11, 2017.

Accepted August 11, 2017.

${ }^{1}$ Corresponding author: elsa.vasseur@mcgill.ca lameness prevalence, which highlights that lameness detection continues to be difficult in in all housing systems, especially in TS herds. Training to improve detection, record keeping, identification of farm-specific risk factors, and treatment planning for lame cows is likely to help decrease lameness prevalence.

Key words: lameness prevalence, producer perception, tiestall, freestall, automated milking system

\section{INTRODUCTION}

Lameness is one of the most important welfare and productivity concerns in the dairy industry (Whay et al., 2003) and the number 1 animal health concern of Canadian dairy farmers and veterinarians (Bauman et al., 2016). Lameness is often a result of pain in the limb or hoof of a dairy cow. Eighty-one percent of UK dairy producers reported feeling sorry for lame cows, which motivated their action to treat lameness (Leach et al., 2010), whereas UK cattle practitioners reported that treatment of both sole ulcers and digital dermatitis lesions was moderately painful (Huxley and Whay, 2006).

Although many in the dairy industry are concerned about lameness, the prevalence remains high. North American estimates suggest 21 to $55 \%$ of cows in freestall (FS) housing with a milking parlor are lame (Espejo et al., 2006; Ito et al., 2010; von Keyserlingk et al., 2012; Solano et al., 2015), with $46 \%$ of cows having hoof lesions (Cramer et al., 2008). Although tiestall (TS) barns account for $72 \%$ of Canadian dairy farms and 38\% in the United States (Barkema et al., 2015), estimates of lameness prevalence in TS dairies are scarce. Early studies on TS herds conducted in Ontario, Canada, found lower estimates of lameness prevalence (3\%; Zurbrigg et al., 2005) and hoof lesions (26\%; Cramer et al., 2009) than typically reported in FS farms. However, the most recent lameness prevalence in Canadian TS herds reported was around $24 \%$ (Charlton et al., 2016). Automated milking systems 
(AMS) account for $5 \%$ of the dairies in Canada, but the numbers are increasing every year (Tse, 2016). To our knowledge, only one recent epidemiological study reported lameness prevalence in herds with an AMS, which was around $15 \%$ in Canada and United States (Westin et al., 2016a).

The continued high prevalence of lameness and the large variation in lameness prevalence among herds (Solano et al., 2015) indicate that producers have difficulty in successfully decreasing lameness in their herds. Dairy producers in the United Kingdom reported that time, labor, and financial constraints limit their ability to decrease lameness in their herds (Leach et al., 2010). Other possible barriers in lameness control may include a lack of awareness of the problem, ignoring the cause, or even underestimating the severity of the issue (Bell et al., 2009; Leach et al., 2010). Indeed, it has been reported that UK and US producers substantially underestimate the prevalence of lameness in their herds by 26 to $40 \%$ compared with trained assessors (Wells et al., 1993; Whay et al., 2003; Espejo et al., 2006). Those studies were conducted in FS dairy farms with a milking parlor; no similar studies were conducted in TS or AMS farms.

To provide some explanation of challenges in reducing lameness prevalence on Canadian dairies, the objectives of our study were to examine the accuracy of producers' estimates of lameness prevalence and their perceptions of the importance of lameness and risk factors, and to investigate how producers monitor lameness in TS, FS and AMS herds. Lameness prevalence (as determined by trained observers) and the related environmental risk factors were reported in Charlton et al. (2016) for TS farms, in Solano et al. (2015) for FS farms, and Westin et al. (2016a) for AMS farms. In this manuscript, the lameness prevalence determined by trained observers is compared with producer's estimates and producer's perceptions (perceived importance) of lameness.

\section{MATERIALS AND METHODS}

The methodology for determining farm and cow selection and lameness prevalence (as estimated by researchers) in our study are also described in detail for TS herds in Charlton et al. (2016), for FS herds in Solano et al. (2015), and for AMS herds in Westin et al. (2016a). The salient points for the questions addressed in this paper are presented in more detail here.

\section{Farm Information}

A total of 100 TS farms, 112 FS farms with a milking parlor (referred to as FS herds), and 25 freestall farms with AMS (referred to as AMS herds) were visited in the Canadian provinces of Québec (January-April 2012), Ontario (May-November 2011), and Alberta (May 2011-July 2012). Farms were enrolled as part of a cross-Canadian epidemiological study aimed at the implementation of a cow welfare assessment protocol (Vasseur et al., 2015). Inclusion criteria for farm enrollment in the study were enrollment in a DHI program (with the exception of AMS herds), average milk production $>7,000 \mathrm{~kg} /$ cow per year, herd size $>40$ lactating cows, Holstein-Friesian breed, cows housed in their present barn and stalls for at least $1 \mathrm{yr}$, and no access to outdoor exercise or pasture. These criteria were chosen to ensure surveyed farms would be representative of the housing and management situation on the majority of Canadian dairy farms. Farms were also selected to have variation in average cow longevity, defined by both percent of cows in 3rd lactation and higher and the annual turnover rate (see Vasseur et al., 2015). In Alberta, all selected farms were also enrolled in another project (The Alberta Dairy Hoof Health Project; Alberta Milk, 2013). Farmers were invited to participate in the study by mail and, after they returned a letter indicating their willingness to participate, they were interviewed over the phone to determine if they met the study inclusion criteria. Herd size and milk production of the surveyed farms [only CanWest DHI (Guelph, Ontario, Canada) and Valacta Inc. (Sainte-Anne-de-Bellevue, Québec, Canada) DHI recording herds were included] is presented in Table 1.

\section{Lameness Prevalence}

During farm visits, 40 focal cows on each farm were scored for lameness. The sample size was calculated to obtain a reliable estimate of lying time, which was the primary target measure in our cow comfort assessment (Vasseur et al., 2012b, 2015). Sample size of 40 cows accounted for 61,25 , and $38 \%$ of average herd size in TS, FS and AMS herds, respectively. Focal cows were selected between 10 and 120 DIM; if the herd had $<40$ cows between 10 and 120 DIM, the selection criterion was increased with cows $>120$ DIM until a sample of 40 cows was obtained. In contrast, if the herd had $>40$ cows between 10 and 120 DIM, the sample of focal cows was balanced to reflect the ratio of primiparous and multiparous cows in the herd. The method used for cow selection was targeted to early- to mid-lactation cows (high-producing group) that are at higher risk of lameness (Green et al., 2014).

On FS and AMS farms, video-recordings of the cows were made while they were walking in a straight line at a steady pace for a minimum of 2 strides either as they 
exited the milking parlor (FS) or when released from the headlocks (AMS). The videos of the cows walking were evaluated by trained assessors, and a cow was scored as lame if she had an obvious limp, which was defined as uneven weight bearing on 1 or more limbs; a simplified version of a numerical rating score (Flower and Weary, 2006), which was previously used to detect lame cows in commercial facilities (Ito et al., 2010). If a cow moved at a trot or a run, the video was disregarded and the data not included. The video was watched twice by 1 of the 7 trained assessors to determine lameness score for each cow. Twenty percent of the videos $(\mathrm{n}=$ 1,072 ) were scored a second time by a second trained assessor to assess inter-rater reliability. Overall exact agreement for the 7 assessors was $94 \%$ for limp.

On TS farms, cows were scored for lameness while standing in their stall using the TS lameness score adapted from Leach et al. (2009) and validated by Gibbons et al. (2014). The inter- and intraobserver repeatability of this method and its accuracy in assessing the prevalence of lameness on a commercial farm in comparison with gait scoring has been described by Gibbons et al. (2014). Video recordings of the cows were made while they were assessed in their stall. The videos of the cows were watched by trained assessors, and a cow was scored as lame if she showed at least 2 of the following behaviors: (1) weight shift: regular, repeated shifting of weight from one hoof to another, defined as lifting each hind hoof at least twice off the ground; (2) stand on edge: the cow places one or more hooves on the edge of the stall while standing stationary; (3) uneven weight: repeatedly resting one foot more than the other, which was indicated by the cow raising a part of the hoof or the entire hoof off the ground; and (4) uneven movement: uneven weight bearing between feet when the cow was encouraged to move from side to side (Leach et al., 2009; Gibbons et al., 2014). The video was watched twice 1 of the 8 trained assessors to determine lameness score for each cow. Twenty percent of the videos $(\mathrm{n}=800)$ were scored a second time by a second trained assessor to measure inter-rater reliability. Overall exact agreement for the 8 assessors was $92 \%$ for all 4 behavioral indicators.

\section{Lameness Management Survey and Producers' Estimates}

During farm visits, each producer was interviewed on lameness management using a survey questionnaire covering 3 aspects, namely (1) producer's perception of major health issues in their herd, (2) producer's perception of the extent that lameness was a problem in their herd, and (3) producer's monitoring of lameness. The answers to 16 questions were either qualitative nominal (e.g., "In the past 2 years, have you made any management changes to deal with lameness?" Answer: yes vs. no) or qualitative ordinal [e.g., "How important is 'reduced milk production' resulting from lameness?" Scale of answer: 1 (not important) to 5 (extremely important)]. The complete questionnaire can be found on the Canadian Dairy Research Portal (2. Questionnaire: Assessing cow management; https://www.dairyresearch .ca/animal-comfort-tool.php); this manuscript refers specifically to questions 13 to 29.

Producers were asked during the interview to estimate the number of cows that were lame at the day of the visit, which was used to calculate herd point prevalence. Few producers kept good records of cow lameness on their farms; thus, records could not be used to obtain their estimates of prevalence. We also asked producers whether or not they considered lameness to be a major, moderate, minor, or not a problem on their farms. To evaluate if producers perceive financial losses through lameness management, we asked producers to estimate the cost for each lameness case (including hoof trimming, lameness treatments, and milk loss, among others). Options were $<\$ 100, \$ 100$ to $200, \$ 200$ to 400 , and $>\$ 400$. Finally, producers were asked how painful lameness is for a cow, with options of slightly, moderately, very, or not at all painful.

Table 1. Mean \pm SD (minimum-maximum) herd size (number of lactating cows) and milk production (kg/ cow per year) of participating farms per housing type

\begin{tabular}{lcrc}
\hline Housing type & No. of farms $^{1}$ & Herd size & Milk production \\
\hline Freestall $^{2}$ & 109 & $160 \pm 94(47-513)$ & $9,921 \pm 978(7,321-12,160)$ \\
Tiestall $_{\text {Freestall with } \mathrm{AMS}^{3}}^{100}$ & $66 \pm 17(43-121)$ & $9,570 \pm 875(7,511-11,870)$ \\
\hline
\end{tabular}

${ }^{1}$ Only farms enrolled with CanWest DHI (Guelph, Ontario, Canada) or Valacta Inc. (Sainte-Anne-de-Bellevue, Québec, Canada) DHI program were included. Values are averaged over 3 yr (2008-2011).

${ }^{2}$ With milking parlor.

${ }^{3} \mathrm{AMS}=$ automated milking system. 


\section{Statistical Analyses}

All statistics were performed using SAS version 9.2 (SAS Institute Inc., Cary, NC). A $P$-value $\leq 0.05$ was considered statistically significant, whereas a $P$-value $>0.05$ and $\leq 0.10$ was considered a tendency. Data were assessed for non-normality through examination of residuals. To compare estimates of prevalence of lameness between researchers and farmers, the Spearman's correlation between the 2 estimated prevalences was calculated. The correlation between prevalence estimates and producer-selected categories of importance of the lameness problem on their farm was determined. Least squares means were used to calculate estimates of producer- and researcher-estimated prevalence associated with each category of lameness perceived by producers (i.e., not a problem, a minor, moderate, or major problem). Finally, chi-squared tests on contingency tables were used to determine if producer responses differed by housing type for categorical responses. The percent of producers responding was used for all questions, except when asked when producers decide to treat an identified case of lameness and when they check routinely for lameness. In these questions, multiple options could be selected, so the percentage of responses was used rather than the percent of producers responding. To test whether selection bias on cow sample size (i.e., 40 cows representing more cows relative to total herd size evaluated for lameness in small herds than in larger herds) and cow selection (i.e., 40 cows selected from early lactation cows) had skewed reported prevalence, we checked if the discrepancies between researcher estimates and producer estimates of prevalence varied according to herd size.

\section{RESULTS}

\section{Lameness Prevalence and Producer Estimates}

Producers estimated the mean herd-level lameness prevalence to be $9.0 \%( \pm 0.9 \% ; \pm \mathrm{SE})$, compared with $22.2 \%( \pm 0.9 \%)$ as estimated by researchers. Mean researcher-estimated prevalences were $4.1,1.8$, and 1.6 times higher than estimated by producers for TS, FS, and AMS farms, respectively. Discrepancies between researcher estimates and producer estimates of prevalence did not vary according to herd size $(\mathrm{r}=-0.05$; $P=0.43$ ), allowing us to disregard potential skewed reported prevalence linked to the selection criteria of sample size and cow selection. The correlation between the researcher- and producer-estimated prevalence was low $(\mathrm{r}=0.19 ; P=0.005)$. Of the 237 farms that had both researcher and producer estimates of the

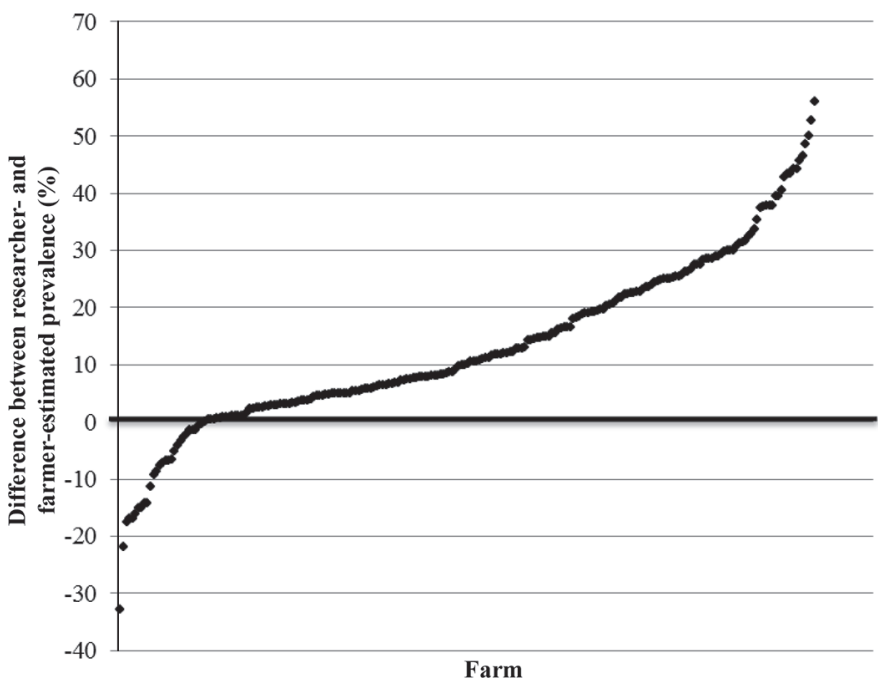

Figure 1. Absolute difference between trained observer-estimated prevalence $(\%)$ and producer-estimated prevalence of lameness at the farm level $(\mathrm{n}=237)$.

prevalence of lameness, only 26 producers estimated the prevalence of lameness to be higher than did the researchers (mean absolute difference $11.2 \%$, range $=$ 0.4-32.8\%), whereas the remainder estimated lameness prevalence to be lower than did the researchers (mean absolute difference $16.2 \%$, range $=0.4-56.1 \%$; Figure $1)$.

\section{Perception of Lameness}

When asked about the degree to which lameness was considered a problem, $48 \%$ of producers thought lameness was a moderate or major problem in their herds (Table 2). Producers were more likely to consider lameness as a problem if they estimated that the prevalence was high (Table 2). The association with the researcher estimates of lameness was prevalence was in the same direction but not as strong (Table 2). The perception that lameness was a problem or not differed with farm type $(P=0.01)$, with $53 \%$ of producers on AMS farms, $59 \%$ on FS farms, and $34 \%$ on TS farms believing lameness was a moderate or major problem in their herd.

When asked to rank the 3 most important health problems, $29 \%$ of producers selected lameness as the highest ranked health problem they were trying to control, after mastitis (32\%) and just ahead of fertility problems (29\%). When ranked based on cost to the business, $24 \%$ of producers selected lameness as the highest ranked health problem, after fertility issues $(38 \%)$ and mastitis (28\%). Ranking the effort put into controlling lameness and the perceived costs of lameness differed by housing type $(P=0.0001$; Figure 2$)$, 
Table 2. Producers' perceptions whether lameness was a problem and mean estimates of lameness prevalence by the producer and trained observers (LSM)

\begin{tabular}{lccc}
\hline $\begin{array}{l}\text { Producer perception of lameness } \\
\text { as a problem }\end{array}$ & No. of farms & $\begin{array}{c}\text { Mean producer estimated } \\
\text { prevalence (95\% CI) }\end{array}$ & $\begin{array}{c}\text { Mean researcher estimated } \\
\text { prevalence (95\% CI) }\end{array}$ \\
\hline Not a problem & 13 & $1.7(1.1,2.7)$ & $14.5(9.4,21.7)$ \\
Minor problem & 111 & $4.7(4.0,5.5)$ & $15.1(13.1,17.5)$ \\
Moderate problem & 100 & $9.7(8.2,11.3)$ & $21.5(18.7,24.7)$ \\
Major problem & 13 & $19.1(12.6,27.8)$ & $25.9(17.7,36.3)$ \\
\hline
\end{tabular}

with estimates of both being higher in AMS and FS farms than on TS farms.

Overall, $58 \%$ of producers had made management changes to deal with lameness in the past 2 yr. This differed by housing type $(P=0.001)$, with $43 \%$ of TS,

A

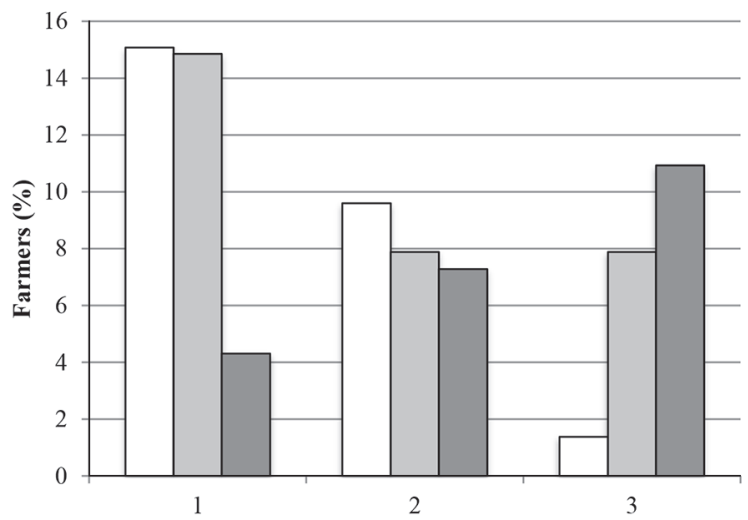

口AMS 口FS 口TS

B

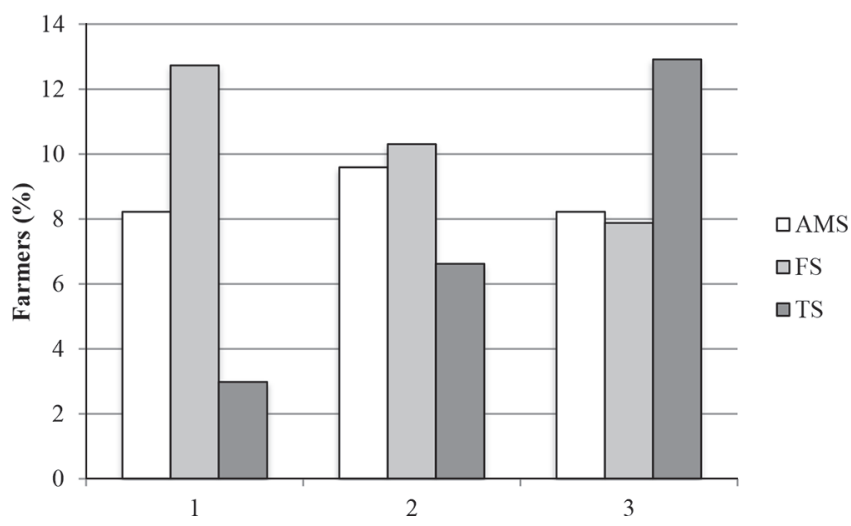

Figure 2. (A) Ranking of effort put into controlling lameness compared with other health problems (mastitis and fertility) in 3 housing types. Values from 1 (greatest) to 3 (lowest) indicate the amount of effort. (B) Ranking on cost of lameness to the business compared with other health problems (mastitis and fertility) in 3 housing types. Values from 1 (greatest) to 3 (lowest) indicated the cost. Housing type: freestall with milking parlor (FS; $\mathrm{n}=112$ ), tiestall (TS; $\mathrm{n}=100$ ), automatic milking system (AMS; $\mathrm{n}=25)$.
$70 \%$ of FS and $62 \%$ of AMS producers stating they have made changes. Eighty-seven percent of the producers that stated they made changes gave specific reasons for these management changes. Most producers (39\%) stated that high lameness prevalence was the reason for change, and $17 \%$ gave a specific hoof lesions as a reason (most commonly digital dermatitis; however, in a few cases, foot rot and sole ulcers were named). Improving cow comfort and improving hoof trimming were listed as reasons for management changes in 4 and $8 \%$ of changes, respectively.

Rankings of importance for various causes of lameness differed by housing type $(P<0.0001$; Table 3$)$, with hoof infection or poor hygiene being the most frequently listed by FS and AMS farms, whereas uncomfortable stalls were most frequently listed by TS farms. Importance of issues arising from lameness also differed by housing type $(P<0.0001$; Table 3$)$, with reduced milk production being the most frequently listed by FS farms, whereas pain for the cow was the most frequently listed by AMS and TS farms. When asked how painful producers believed lameness to be, $30 \%$ of producers thought it was moderately painful whereas $69 \%$ of producers suggested it was very painful, which was not different among housing types $(P=0.76)$.

Finally, when ranking factors that prevent producers from treating lame cows, responses differed by housing type $(P<0.0001$; Table 3$)$. A lack of time was most frequently listed for all housing types, but this reason was listed less frequently in TS farms than on FS and AMS farms. A lack of skilled labor was less frequently listed on AMS farms than on TS and FS farms.

Seventy-three percent of producers thought that the cost of an average lameness case was Can $\$ 200$ or more, which did not differ by housing type $(P=0.23)$. Five percent of producers estimated that each lameness case cost them less than Can $\$ 100$.

\section{Lameness Monitoring}

Almost all producers (98\%) stated that they routinely checked cows to identify new cases of lameness, which did not differ by housing type $(P=0.41)$. A majority $(92 \%)$ of producers did a visual evaluation as part of 
their daily routines, and $2 \%$ performed visual evaluations as part of a weekly routine. Less than $1 \%$ of farmers mentioned that specialists were used to identify new cases. Producers reported that the main occasions for detecting lameness included when walking around the barn, when feeding cows, when moving cows to or from the milking parlor, or at other times. Walking around the barn was the most commonly listed occasion for lameness monitoring (overall $62 \%$ of producers; TS = $74 \%, \mathrm{FS}=47 \%$, AMS $=85 \%$ ). In FS farms, $94 \%$ of producers observed cows for lameness when cows were moved into the milking parlor and $48 \%$ when the cows were moved out of the milking parlor. A minority of producers observed cows for lameness detection at the time of feeding $(\mathrm{TS}=10 \%, \mathrm{FS}=12 \%$, AMS $=19 \%$ ). Producers in FS farms were more likely to check cows on multiple occasions (68\%) compared with producers on AMS $(39 \%)$ or TS $(25 \%)$ farms $(P<0.0001)$.

Producers were asked what signs were used to detect lame cows with 3 options provided: when a cow limps, when a cow does not want to stand up (e.g., for milking, at feeding), and when a cow has a back arch. Limping was the most common sign used by producers to diagnose lameness, with $81 \%$ of producers using a limp as an indication. Cows that did not want to stand up and back arches were also commonly used as signs, with 47 and $35 \%$ of producers using these signs, respectively. Lameness detection was done using multiple signs of lameness by $65 \%$ of producers that checked for lame cows routinely. Of the TS producers, $49 \%$ used only 1 sign, whereas $30 \%$ of FS producers and $4 \%$ of AMS producers used only 1 sign $(P=0.0008)$.

Forty percent of producers did not keep records of lameness (60\% of TS, $23 \%$ of FS, and $24 \%$ of AMS).
Producers most commonly recorded the cases of lameness treated and cases of lameness that hoof trimmers reported, with 34 and $33 \%$ of producers stating they used these methods, respectively. Cows culled due to lameness $(21 \%)$ were recorded, and least frequently all detected lameness cases were recorded (13\%).

A majority $($ mean $=69 \%)$ of producers treated lame cows themselves immediately after detection (TS = $57 \%, \mathrm{FS}=82 \%, \mathrm{AMS}=73 \%$ ). A total of $13 \%$ of waited until the hoof trimmer or veterinarian came for cows to be treated $(\mathrm{TS}=20 \%, \mathrm{FS}=8 \%, \mathrm{AMS}=0 \%)$. The veterinarian or hoof trimmer was called immediately by $8 \%$ of farms ( $\mathrm{TS}=13 \%, \mathrm{FS}=2 \%$, AMS $=19 \%$ ), whereas a mean of $9 \%$ of farmers would waited to see if the cows got better $(\mathrm{TS}=10 \%, \mathrm{FS}=7 \%, \mathrm{AMS}=8 \%$ ). Only 1 producer did not treat lame cows.

\section{DISCUSSION}

The majority of producers considerably underestimated the prevalence of lameness on their farms. On average, the trained researchers reported lameness prevalence to be 3.6 times higher than did producers. This confirms other studies, with researchers' reports of lameness prevalence being 2.5 (United States; Wells et al., 1993), 3.1 (United States; Espejo et al., 2006), and 3.9 (United Kingdom; Whay et al., 2003) times that of farm staff. Overall, slightly more than $50 \%$ of surveyed producers stated that lameness was not or was only a minor problem on their farm. The perception that lameness is not a major problem likely results from underestimating the prevalence of lameness in their herds. Producers who stated that lameness was not a problem on their farm reported a much lower prevalence of

Table 3. Percentage of producers ranking causes of lameness, issues arising from lameness, and factors preventing the control of lameness as very or extremely important by housing type

\begin{tabular}{lccc}
\hline Item & $\begin{array}{c}\text { Freestall } \\
(\mathrm{n}=112)\end{array}$ & $\begin{array}{c}\text { Tiestall } \\
(\mathrm{n}=100)\end{array}$ & $\begin{array}{c}\text { AMS }^{2} \\
(\mathrm{n}=25)\end{array}$ \\
\hline Cause & & & 88 \\
Foot infection/poor hygiene & 77 & 76 & 76 \\
Nutrition & 74 & 81 & 72 \\
Uncomfortable stalls & 72 & 77 & 84 \\
Bad flooring & 71 & 88 & 85 \\
Issue & 95 & 90 & 88 \\
Reduced milk production & 85 & 83 & 32 \\
Pain for the cow & 77 & 21 & 8 \\
$\quad$ Reduced fertility & 35 & 15 & 8 \\
Factor preventing control & 20 & 12 & \\
Lack of time & 10 & &
\end{tabular}


lameness than producers who stated that lameness was a major problem (1.7 vs. 19.1\%); however, the difference in the prevalence as reported by trained researchers was much smaller ( $14.5 \%$ versus $25.9 \%$ ). Similar results have been reported for other dairy cattle health issues, where producers' perception of the importance of a health problem did not match up with the actual intensity of the problem (e.g., calf mortality; Vasseur et al., 2012a). It is essential that farmers are aware of the magnitude of the lameness problem in their dairy herd. Awareness is needed for the motivation to prevent and control lameness in their herd (Ritter et al., 2017).

Lameness was perceived as the second most important health problem to control, after mastitis and tied with fertility problems, a ranking similar to that of European producers (Leach et al., 2010). In a large Canadian study, lameness was ranked even higher, as the number one disease problem on dairy farms (Bauman et al., 2016).

Lack of knowledge about causes and risk factors for lameness did not seem to explain why less effort was put into lameness control compared with other diseases. The producers were aware of the main risk factors for lameness; most producers identified hygiene (Rodriguez-Lainz et al., 1996), uncomfortable stalls (Dippel et al., 2009), and flooring (Somers et al., 2003; Sogstad et al., 2005). However, producers may not realize that the risk factors are present on their own farm. This is supported by findings that the majority of stalls on Canadian dairy farms do not meet recommendations for stall design, and that this is associated with an increased prevalence of lameness and leg lesions (e.g., Bouffard et al., 2017). However, this may reflect the cost and difficulty of making changes to housing rather than awareness. Furthermore, the majority of producers listed poor nutrition as a major risk factor for lameness even though there is not a great deal of evidence that poor nutrition is an actual risk factor on modern dairy farms (Bell et al., 2009); extension efforts should focus on identifying farm-specific risk factors. Additionally, farmers will be reluctant to make changes if they are not convinced that they can implement the changes and that they will effectively decrease lameness prevalence (Ritter et al., 2017). Knowledge about foot health management increased adoption of control practices (Bruijnis et al., 2013). It is therefore very important that extension activities focus on improving the knowledge of dairy farmers and their advisors on lameness and lameness control.

Producers on both FS and AMS farms were putting more effort into lameness control than producers on TS farms. A similar pattern was observed for the management changes made over the last $2 \mathrm{yr}$, with those with TS housing indicating that fewer changes had been made. This may be due to the availability of management procedures for lameness control in herds where cows move throughout the barn, such as footbaths, compared with TS farms, where these management procedures of control are unavailable. The more severe underestimation of the lameness prevalence by TS farmers likely also played a role in their reducing motivation to focus more on lameness control on farm.

A lack of success in lameness control did not seem to result from producers thinking that lameness was not painful for the cow or from their underestimating the costs of lameness. Ninety-nine percent of producers stated they believed lameness to be moderately or very painful to the cow, which has been demonstrated by research (Whay et al., 1998; Hernandez et al., 1999; Dyer et al., 2007; Higginson Cutler et al., 2013). The majority of producers believed that lameness cost more than Can $\$ 200$ per case, which is within the range of recent estimates reported from the United States (Ettema and Ostergaard, 2006; Cha et al., 2010). The high prevalence of lameness on dairy farms does not appear to result from a lack of treatment either. As most producers acknowledge that lameness is painful to the cow and are aware of the costs of lameness, most give prompt treatment; only a small minority did not report treating lameness immediately. Lack of time and skilled labor on farm were the most common reasons for lack of lameness control, which are the same factors that Leach et al. (2010) found were given to explain a lack of effort to control lameness by UK farmers. In a follow-up study, Bennett et al. (2014) showed that although dairy farmers claim to be willing to pay substantial sums to reduce lameness, in reality, they do not always take the courses of action that are available to them to reduce the number of lame cows in their herds. The reasons expressed were disbelief that lameness could be eliminated in their herds as well as the inconvenience associated with several lameness control measures. Farmers were not surveyed on those aspects as part of our study; however, the conclusions of Bennett et al. (2014) could be generalized to encourage actions, as farmers need to be convinced about the cost effectiveness of lameness control measures.

Although all producers indicated that they were monitoring lameness as part of their daily routine, many were not able to estimate prevalence on their farms accurately and most of them underestimated lameness prevalence. This may reflect a difference between producers and trained researchers in the threshold of how severe changes in gait must be before the cow is considered as lame. This disagreement in the definition of a lame cows was also discussed by Leach et al. 
(2010). Alternatively, producers may not be using valid and accurate signs for detecting lameness or not be sufficiently trained in detection (also discussed in Sarova et al., 2011). The majority of FS and AMS producers observe the gait of the cow for a visible limp; however, gait scoring is a qualitative assessment of lameness and such assessments require continuous training of the assessors to ensure accuracy of the diagnostic (e.g., injuries in Gibbons et al., 2012; BCS in Vasseur et al., 2013). Opportunities exist for extension and training materials are available to improve the lameness detection rates on FS farm (e.g., Firm Steps: Identifying lameness in dairy cattle CD-Rom evaluation; Alberta Agriculture and Rural Development, 2014).

However, gait scoring is particularly difficult for producers in TS farms, who had the most difficulty detecting lameness. On these farms, producers only reported $23 \%$ of cases detected by researchers. Efforts to transfer appropriate methods to TS producers are therefore essential to assist in identification of lame cows in these systems. A new lameness-detection system for tethered cows that does not require releasing cows from their stall has been developed (Leach et al., 2009) and validated for on-farm use (Gibbons et al., 2014; Palacio et al., 2017). This stall lameness scoring provides new signs that could be used by TS farmers for lameness detection by observing 4 behavioral indicators while cows are still in their stalls: weight shifting (shift), standing on the edge of the stall (edge), uneven weight bearing while standing (rest), and uneven weight bearing while moving from side to side (uneven). These signs are more specific to TS cows than signs currently reported by TS farmers. Automatic tools currently exist to continuously monitor behavior and activity levels of dairy cows and are becoming more common on farms (Vasseur, 2017), especially in AMS. Automated systems measuring activity (Mazrier et al., 2006) and lying behavior show promise for lameness detection in all housing systems (TS: Charlton et al., 2016; FS: Solano et al., 2016; AMS: Westin et al., 2016b).

Record keeping is essential to estimate lameness incidence accurately and determine whether improvements made on farm are effective; however, keeping standardized, valid, and systematic health data at the herd level is challenging (LeBlanc et al., 2006; Vasseur et al., 2012a). Almost 40\% of producers interviewed stated they did not keep lameness records. The need for lameness monitoring that is required for certain auditing schemes (e.g., proAction Initiative by Dairy Farmers of Canada, 2016) may provide a good incentive to implement systematic recording of lameness and the development of control strategies on farms.

\section{CONCLUSIONS}

Lameness detection remains challenging in all housing systems. Producers are aware of the general risk factors for lameness and that lameness is expensive and painful for the cow, and producers are monitoring for lameness as part of their daily routine. Despite this, the prevalence of lameness on Canadian dairy farms remains high, which may partly be due to producers' underestimating the prevalence of lameness. Another reason may be that, although producers are knowledgeable on the main risk factors for lameness, they may not realize that the risk factors are present on their individual farm. Additionally, recording of lameness is still lacking. Training to improve detection methods and improve treatment, along with automated tools to facilitate lameness monitoring, will most likely help producers to decrease lameness prevalence.

\section{ACKNOWLEDGMENTS}

This study was funded by Agriculture and Agri-Food Canada (AAFC; Ottawa, Ontario, Canada), the Canadian Dairy Commission (Ottawa, Ontario, Canada), and Dairy Farmers of Canada (Ottawa, Ontario, Canada) as part of the Dairy Science Cluster initiative supported by the AgriInnovation Program of AAFC's Growing Forward Policy Framework (a federal-provincial-territorial initiative), as well as Fonds Québecois de la Recherche sur la Nature et les Technologies (FQRNT; Québec City, Québec, Canada), Novalait (Québec City, Québec, Canada), Ministère de l'Agriculture, des Pêcheries et de l'Alimentation du Québec (MAPAQ; Québec City, Québec, Canada), and by Alberta Milk (Edmonton, Alberta, Canada). We thank all collaborators, graduate and research undergraduate students from University of British Columbia (Vancouver, British Columbia, Canada), University of Calgary (Alberta, Canada), University of Guelph (Ontario, Canada), Université Laval (Québec city, Québec, Canada), Valacta (Sainte-Anne-de-Bellevue, Québec, Canada), and CanWest DHI (Guelph, Ontario, Canada), as well as all dairy producer participants. We acknowledge Katherine Leach from University of Bristol (Bristol, UK) for graciously sharing her questionnaire survey.

\section{REFERENCES}

Alberta Agriculture and Rural Development. 2014. Firm steps: Identifying lameness in dairy cattle Agdex 410/20-1. Accessed Mar. 30, 2017. http://www1.agric.gov.ab.ca/\$department/deptdocs.nsf/ all/aet11477. 
Alberta Milk. 2013. Dairy cattle hoof health. Accessed Mar. 30, 2017. ftp://s173-183-201-52.ab.hsia.telus.net/Inetpub/wwwroot/ HoofHealth/Index.html.

Barkema, H. W., M. A. von Keyserlingk, J. P. Kastelic, T. J. Lam, C. Luby, J. P. Roy, S. J. LeBlanc, G. P. Keefe, and D. F. Kelton. 2015. Invited review: Changes in the dairy industry affecting dairy cattle health and welfare. J. Dairy Sci. 98:7426-7445.

Bauman, C. A., H. W. Barkema, J. Dubuc, G. P. Keefe, and D. F. Kelton. 2016. Identifying management and disease priorities of Canadian dairy industry stakeholders. J. Dairy Sci. 99:10194-10203.

Bell, N. J., M. J. Bell, T. G. Knowles, H. R. Whay, D. C. J. Main, and A. J. F. Webster. 2009. The development, implementation and testing of a lameness control programme based on HACCP principles and designed for heifers on dairy farms. Vet. J. 180:178-188.

Bennett, R. M., Z. E. Barker, D. C. J. Main, H. R. Whay, and K. A. Leach. 2014. Investigating the value dairy farmers place on a reduction of lameness in their herds using a willingness to pay approach. Vet. J. 199:72-75.

Bouffard, V., A. M. de Passillé, J. Rushen, C. G. R. Nash, D. B. Haley, and D. Pellerin. 2017. Effect of following recommendations for tiestall configuration on neck and leg lesions, lameness, cleanliness, and lying time in dairy cows. J. Dairy Sci. 100:2935-2943.

Bruijnis, M., H. Hogeveen, C. Garforth, and E. Stassen. 2013. Dairy farmers' attitudes and intentions towards improving dairy cow foot health. Livest. Sci. 155:103-113.

Cha, E., J. A. Hertl, D. Bar, and Y. T. Gröhn. 2010. The cost of different types of lameness in dairy cows calculated by dynamic programming. Prev. Vet. Med. 97:1-8.

Charlton, G. L., V. Bouffard, J. Gibbons, E. Vasseur, D. B. Haley, D. Pellerin, J. Rushen, and A. M. de Passillé. 2016. Invited paper: Can automated measures of lying time help assess lameness and leg lesions on tie-stall dairy farms? Appl. Anim. Behav. Sci. $175: 14-22$.

Cramer, G., K. Lissemore, C. Guard, K. Leslie, and D. Kelton. 2008. Herd- and cow-level prevalence of foot lesions in Ontario dairy cattle. J. Dairy Sci. 91:3888-3895.

Cramer, G., K. D. Lissemore, C. L. Guard, K. E. Leslie, and D. F. Kelton. 2009. Herd-level risk factors for seven different foot lesions in Ontario Holstein cattle housed in tie stalls or free stalls. J. Dairy Sci. 92:1404-1411.

Dairy Farmers of Canada. 2016. proAction initiative, animal care assessment program. Accessed Apr. 11, 2017. https://www .dairyfarmers.ca/proaction\#animal-care.

Dippel, S., M. Dolezal, C. Brenninkmeyer, J. Brinkmann, S. March, U. Knierim, and C. Winckler. 2009. Risk factors for lameness in freestall-housed dairy cows across two breeds, farming systems, and countries. J. Dairy Sci. 92:5476-5486.

Dyer, R. M., N. Neerchal, U. Tasch, Y. Wu, P. Dyer, and P. Rajkondawar. 2007. Objective determination of claw pain and its relationship to limb locomotion score in dairy cattle. J. Dairy Sci. 90:4592-4602.

Espejo, L. A., M. I. Endres, and J. A. Salfer. 2006. Prevalence of lameness in high-producing Holstein cows housed in freestall barns in Minnesota. J. Dairy Sci. 89:3052-3058.

Ettema, J. F., and S. Ostergaard. 2006. Economic decision making on prevention and control of clinical lameness in Danish dairy herds. Livest. Sci. 102:92-106.

Flower, F. C., and D. M. Weary. 2006. Effect of hoof pathologies on subjective assessments of dairy cow gait. J. Dairy Sci. 89:139-146.

Gibbons, J., D. Haley, J. Higginson Cutler, C. Nash, J. Zaffino Heyerhoff, D. Pellerin, S. Adam, A. Fournier, A. M. de Passille, J. Rushen, and E. Vasseur. 2014. Reliability and validity of a method to measure lameness prevalence in tie-stalls. J. Dairy Sci. 97:350-353.

Gibbons, J., E. Vasseur, J. Rushen, and A. M. de Passillé. 2012. A training program to ensure high repeatability of injury scoring of dairy cows. Anim. Welf. 21:379-388.

Green, L. E., J. N. Huxley, C. Banks, and M. J. Green. 2014. Temporal associations between low body condition, lameness and milk yield in a UK dairy herd. Prev. Vet. Med. 113:63-71.
Hernandez, J., J. Shearer, and J. Elliott. 1999. Comparison of topical application of oxytetracycline and four nonantibiotic solutions for treatment of papillomatous digital dermatitis in dairy cows. J. Am. Vet. Med. Assoc. 214:688-690.

Higginson Cutler, J. H., G. Cramer, J. J. Walter, S. T. Millman, and D. F. Kelton. 2013. Randomized clinical trial of tetracycline hydrochloride bandage and paste treatments for resolution of lesions and pain associated with digital dermatitis in dairy cattle. J. Dairy Sci. 96:7550-7557.

Huxley, J. N., and H. R. Whay. 2006. Current attitudes of cattle practitioners to pain and the use of analgesics in cattle. Vet. Rec. 159:662-668

Ito, K., M. A. G. von Keyserlingk, S. J. Leblanc, and D. M. Weary. 2010. Lying behavior as an indicator of lameness in dairy cows. J. Dairy Sci. 93:3553-3560.

Leach, K. A., S. Dippel, J. Huber, S. March, C. Winckler, and H. R. Whay. 2009. Assessing lameness in cows kept in tie-stalls. J. Dairy Sci. 92:1567-1574.

Leach, K. A., H. R. Whay, C. M. Maggs, Z. E. Barker, E. S. Paul, A. K. Bell, and D. C. J. Main. 2010. Working towards a reduction in cattle lameness: 1 . Understanding barriers to lameness control on dairy farms. Res. Vet. Sci. 89:311-317.

LeBlanc, S. J., K. D. Lissemore, D. F. Kelton, T. F. Duffield, and K. E. Leslie. 2006. Major advances in disease prevention in dairy cattle. J. Dairy Sci. 89:1267-1279.

Mazrier, H., S. Tal, E. Aizinbud, and U. Bargai. 2006. A field investigation of the use of the pedometer for the early detection of lameness in cattle. Can. Vet. J. 47:883-886.

Palacio, S., L. Peignier, C. Pachoud, C. Nash, S. Adam, R. Bergeron, D. Pellerin, A. M. de Passillé, J. Rushen, D. Haley, T. DeVries, and E. Vasseur. 2017. Technical note: Assessing lameness at the stall using live stall lameness scoring. J. Dairy Sci. 100:6577-6582.

Ritter, C., J. Jansen, S. Roche, D. F. Kelton, C. Adams, K. Orsel, R. J. Erskine, G. Benedictus, T. J. G. M. Lam, and H. W. Barkema. 2017. Invited review: Determinants of farmers' adoption of management-based strategies for infectious disease prevention and control. J. Dairy Sci. 100:3329-3347. https://doi.org/10.3168/jds .2016-11977.

Rodriguez-Lainz, A. D. Hird, T. Carpenter, and D. Read. 1996. Casecontrol study of papillomatous digital dermatitis in southern California dairy farms. Prev. Vet. Med. 28:117-131.

Sarova, R., I. Stehulova, P. Kratinova, P. Firla, and M. Spinka. 2011. Farm managers underestimate lameness prevalence in Czech dairy herds. Anim. Welf. 20:201-204.

Sogstad, Å. M., T. Fjeldaas, O. Østerås, and K. Forshell. 2005. Prevalence of claw lesions in Norwegian dairy cattle housed in tie stalls and free stalls. Prev. Vet. Med. 70:191-209.

Solano, L., H. W. Barkema, E. Pajor, S. Mason, S. LeBlanc, J. Zaffino Heyerhoff, C. Nash, D. Haley, D. Pellerin, J. Rushen, A. M. de Passillé, E. Vasseur, and K. Orsel. 2016. Associations between lying time behavior and lameness in Canadian Holstein-Friesian cows in freestall barns. J. Dairy Sci. 99:2086-2101.

Solano, L., H. W. Barkema, E. A. Pajor, S. Mason, S. LeBlanc, J. Zaffino Heyerhoff, C. Nash, D. Haley, D. Pellerin, J. Rushen, A. M. de Passillé, E. Vasseur, and K. Orsel. 2015. Prevalence of lameness and associated risk factors in Canadian Holstein-Friesian cows housed in freestall barns. J. Dairy Sci. 98:6978-6991.

Somers, J. G., K. Frankena, E. Noordhuizen-Stassen, and J. Metz. 2003. Prevalence of claw disorders in Dutch dairy cows exposed to several floor systems. J. Dairy Sci. 86:2082-2093.

Tse, C. 2016. The adoption of automatic milking systems on Canadian dairy farms: Impacts on production, management and dairy producers. MS Thesis. Univ. of Calgary Vet. Med., Calgary, Canada.

Vasseur, E. 2017. Invited Symposium Paper: Optimizing outcome measures of welfare in dairy cattle assessment. J. Anim. Sci. 95:1365-1371. https://doi.org/10.2527/jas.2016.0880.

Vasseur, E., J. Gibbons, J. Rushen, and A. M. de Passillé. 2013. Development and implementation of a training program to ensure high repeatability of body condition score of dairy cows. J. Dairy Sci. 96:4725-4737. 
Vasseur, E., J. Gibbons, J. Rushen, D. Pellerin, E. Pajor, D. Lefebvre and A. M. de Passillé. 2015. An assessment tool to help producers improve cow comfort on their farms. J. Dairy Sci. 98:698-708.

Vasseur, E., D. Pellerin, A. M. de Passille, C. Winckler, B. J. Lensink, U. Knierim, and J. Rushen. 2012a. Assessing the welfare of dairy calves: outcome-based measures of calf health versus input-based measures of the use of risky management practices. Anim. Welf. $21: 77-86$

Vasseur, E., J. Rushen, D. B. Haley, and A. M. de Passillé. 2012b. Sampling cows to assess lying time for on farm animal welfare assessment. J. Dairy Sci. 95:4968-4977.

von Keyserlingk, M. A., A. Barrientos, K. Ito, E. Galo, and D. M. Weary. 2012. Benchmarking cow comfort on North American freestall dairies: Lameness, leg injuries, lying time, facility design, and management for high-producing Holstein dairy cows. J. Dairy Sci. 95:7399-7408.

Wells, S. J., A. M. Trent, W. E. Marsh, and R. A. Robinson. 1993. Prevalence and severity of lameness in lactating dairy cows in a sample of Minnesota and Wisconsin herds. J. Am. Vet. Med. Assoc. 202:78-82.
Westin, R., A. Vaughan, A. M. de Passillé, T. J. DeVries, E. A. Pajor D. Pellerin, J. M. Siegford, E. Vasseur, and J. Rushen. 2016b. Lying times of lactating cows on dairy farms with automatic milking systems and the relation to lameness, leg lesions and body condition score. J. Dairy Sci. 99:551-561.

Westin, R., A. Vaughan, A. M. de Passillé, T. J. DeVries, E. A. Pajor, D. Pellerin, J. M. Siegford, A. Witaifi, E. Vasseur, and J. Rushen. 2016a. Cow and farm-level risk factors for lameness on dairy farms with automated milking systems. J. Dairy Sci. 99:3732-3743.

Whay, H. R., D. Main, L. Green, and A. Webster. 2003. Assessment of the welfare of dairy cattle using animal-based measurements: direct observations and investigation of farm records. Vet. Rec. 153:197-202.

Whay, H. R., A. Waterman, A. Webster, and J. O'Brien. 1998. The influence of lesion type on the duration of hyperalgesia associated with hindlimb lameness in dairy cattle. Vet. J. 156:23-29.

Zurbrigg, K., D. Kelton, N. Anderson, and S. Millman. 2005. Stall dimensions and the prevalence of lameness, injury, and cleanliness on 317 tie-stall dairy farms in Ontario. Can. Vet. J. 46:902-909. 